\title{
Large Granular Lymphocyte
}

National Cancer Institute

\section{Source}

National Cancer Institute. Large Granular Lymphocyte. NCI Thesaurus. Code C12921.

A population of large-sized lymphocytes found in human peripheral blood with slightly eccentric nuclei and abundant cytoplasmic azurophilic granules. This population of cells can be comprised of normal natural killer (NK) cells. 